\title{
РЕТРОСПЕКТИВНЫЙ ВЗГЛЯД НА ИНСТИТУТ СУДЕБНЫХ ПРИМИРИТЕЛЕЙ
}

\section{A RETROSPECTIVE LOOK AT THE INSTITUTION OF JUDICIAL CONCILIATORS}

\section{G. Baranov}

Summary. Federal law of 26.07.2019 N197-FZ "on amendments to certain legislative acts of the Russian Federation" includes the Institute of "judicial reconciliation"in the Civil procedure code of the Russian Federation. The article describes similar institutions that operated in pre-revolutionary Russia.

Keywords: judicial reconciliation; retired judge; courthouse; mediation; civil procedure.

\author{
Баранов Геннадий Александрович \\ Заместитель председателя, Березниковский \\ городской суд Пермского края, г. Березники \\ GennadyyBaranov@yandex.ru
}

Аннотация. Федеральным законом от 26.07.2019 N197-Ф3 «0 внесении изменений в отдельные законодательные акты Российской Федерации» в Гражданский процессуальный кодекс Российской Федерации включен институт «судебного примирения». В статье рассказывается 06 аналогичных институтах, действовавших в дореволюционной России.

Ключевые слова: судебное примирение; судья в отставке; здание суда; медиация; гражданский процесс.
H а основании статьи 5 Федерального закона от 26.07.2019 № 197-Ф3 «О внесении изменений в отдельные законодательные акты Российской Федерации» Гражданский процессуальный кодекс Российской Федерации дополнен главой 14.1 «Примирительные процедуры. Мировое соглашение», в том числе - статьей 153.6 «Судебное примирение» [1].

В соответствии с частью 3 статьи 153.6 Гражданского процессуального кодекса Российской Федерации, судебным примирителем является судья в отставке [1].

В целом, введение института судебного примирения является продолжением развития института медиации, развитие которого началось с принятия Федерального закона от 27.07.2010 № 193-Ф3 «Об альтернативной процедуре урегулирования споров с участием посредника (процедуре медиации)» [2].

Между тем, несмотря на отсутствие подобных институтов в советском праве, в законодательстве и правоприменении дореволюоционной России был накоплен определенный опыт разрешения споров в результате примирительных процедур, в том числе - с помощью специально привлеченных лиц. К сожалению, за время существования СССР он был полностью утрачен.

Представляется, что изучение данного опыта будет полезным для совершенствования медиации и судебного примирения в настоящее время.
Так, первое упоминание о примирительных процедурах с использованием посредников в российском законодательстве упоминается в Новгородской республике, в том числе - в Новгородской берестяной грамоте (1281-1313 годы). Существовала специальная процедура - «мировой ряд», которая предполагала обращение спорящих лиц к услугам «рядцов» (примирителей, посредников) с целью, урегулирования спора и заключения соглашения [3].

По мнению Давыденко Д.Л., процедура «мирового ряда», то есть, разрешение спора с помощью «рядцов», характеризуется следующими особенностями:

1. Мировой ряд не являлся третейским судом. Поскольку рядцы являлись именно посредниками (примирителями), то мировой ряд был именно процедурой достижения мирового соглашения.

2. Мировой ряд не являлся формой посредничества или медиации. По мнению Мартышина O.B., рядцами являлись примирители, избранные сторонами для разрешения споров. При этом, данных рядцов выбирали не сами стороны, но, в целом, новгородская община, число рядцов было неопределенным. К услугам рядцов могли обращаться любые стороны. Решение, принимаемое рядцами, оформлялось письменно и обладало юридической силой, приравненной к силе судебного решения. После того, как рядцы пришли к соглашению, они должны были склонить к нему доверителей. Отличие рядцов от посредни- 
ков в современном смысле являлось в том, они не считались нейтральными, на них возлагались функции договориться между собой об условиях окончания спора [5].

3. Процедура мирового ряда не являлась переговорами представителей. Представители сторон именовались «рассказчиками» и действовали именно в интересах сторон, в том числе и в суде. Рядцы же, действуя во внесудебном порядке, взаимодействовали между собой с целью урегулирования спора. До настоящего времени не ясно, являлись ли согласованные рядцами условия мира обязательными для сторон, либо в некоторых случаях они могли быть ими отклонены. Очевидно, это зависело от уговора сторон, а также от обычая.

Если рядцы приходили к соглашению об условиях разрешения спора, то это оканчивало тяжбу. Пересмотр достигнутых условий мира, по общему правилу, не допускался. Условия мирового соглашения фиксировались в особом документе - рядной грамоте. Исполнение соглашения обеспечивалось предусмотренными в ней санкциями, зачастую, весьма существенными [3].

В целом, следует отметить, что большинство споров, отраженных в грамотах, улаживалось договорным путем и очень многое - по дороге в суд («идя на суд срядяшася») [6].

Также можно отметить деятельность совестных судов, созданных в соответствии с указом Екатерины II от 07.11.1775 года «Учреждения для управления губернией Всероссийской империи».

В данном указе процедура примирения впервые закреплялась законодательно детально. В главе XXVI «О совестном суде и его должности» в ст. 400 «О должности суда» достаточно подробно сформулирована процедура, установлено поэтапное примирение сторон. Сама идея совестного суда заимствована из английского права, автором этой главы был правовед С.Е. Десницкий, который обучался в университете Глазго у А. Смита.

Деятельность этого суда для нас интересна тем, что он был ориентирован на примирение сторон, в том числе - суд привлекал к участию в деле посредников, которые должны были представлять стороны. При этом, посредником мог быть любой человек, в том случае, если он привлекался в этом качестве, то не имел права отказаться. После назначения и объявления посредников суду, спор рассматривался с их участием. На этом этапе посредники должны были найти способ примирения сторон, предъявить его суду, а суд, в свою очередь, его утвердить. Если же посредники не могли найти способ примирения истца и ответчика, то открывался третий этап примирения, в котором суд сам формулировал и предлагал спорящим сторонам идею примирения. В случае несогласия сторон с предложенным судом способом примирения, производство по делу прекращалось, стороны могли обратиться в общие суды для разрешения спора.

К сожалению, несмотря на благие цели, которые преследовались при создании совестных судов, а именно - примирение сторон, облегчение судопроизводства, разгрузка судов, они не получили широкого распространения, поскольку столкнулись с некомпетентностью на местах. По мнению В.Ключевского, за все царствование Екатерины не насчитать и десятка дел, решенных во всех совестных судах надлежащим образом [4].

Совестный суд был ликвидирован на основании высочайше утвержденного мнения Государственного Совета «О штатах совестных судов» от 23 июня 1852 г. Функции этого судебного органа были переданы губернской палате уголовного и гражданского суда.

В данной статье представляется уместным также обратиться к мнению Н.М. Карамзина, которым между 1817-1826 гг. (точная дата неизвестна), был составлен проект рескрипта, который был подан на имя министра юстиции Лобанова-Ростовского. В этом документе Карамзин писал: «Вам известно, какое множество тяжебных дел обременяет наши судебные места. Вникая в причины этого, я убедился в истине, что не одна бессовестная ябеда, но и заблуждение тяжущихся или неясное представление о своих правах бывают виною сего великого зла в отношении к нравственности и к самому гражданскому благосостоянию людей: что благоразумные советы и посредничество лиц, удостоенных общественной достоверности, могли бы устранять или вначале прекращать многие судебные дела способом примирения. Находя сей способ наиболее согласующимся с человеколюбием и святыми правилами христианского закона, я рассудил за благо испытать его».

Далее Карамзин рассказывает, что поручил малороссийскому военному губернатору князю Репину в сентябре месяце 1817 года привлечь к разрешению споров представителей дворянства во вверенных ему губерний. В результате такого привлечения только в двух губерниях было разрешено 574 спора. Данную практику Карамзин предлагал распространить повсеместно [7].

Карамзин, как и подавляющее большинство других мыслителей, был убежден в том, что эффективным и це- 
лесообразным является только то примирение, которое достигнуто добровольно, без давления на участников спора со стороны примирителя.

Также интересно обратиться к опыту деятельности посредников, действовавших при разрешении споров в гражданских и коммерческих судах в России в XIX веке.

14 мая 1832 года было принято «Общее положение об учреждении коммерческих судов в России», которое учредило систему коммерческих судов, по сути - предшественницу системы арбитражных судов сегодня. В деятельности коммерческих судов предусматривалась возможность рассмотрения спора третейским судом, а также процедура мирового разбирательства с участием примирителей.

При подготовке к судебной реформе 1864 года деятельность третейских судов, примирителей была проанализирована.

Так, в объяснительной записке к проекту гражданского судопроизводства указывалось на отзыв министерства юстиции, поступивший 06.05.1849 года. Согласно данного отзыва, деятельность третейских судов признавалась перспективной, поскольку «когда гражданское общество отказалось от самоуправства самосуда, но не было еще правильно устроенных судебных учреждений, спорящие стороны естественно должны были искать мирового разбора в третьем лице, которое, находясь в независимом положении в отношении обоих сторон, пользовалось их обоюдным доверием и решило дело по совести или обычаю».

Между тем, к недостаткам третейских судов были отнесены возможность отмены их решений в течение года по формальным основаниям (нарушение делопроизводства), затянутость сроков рассмотрения дел, в том числе, в связи со злоупотреблением сторонами. Отмечалось крайне незначительное количество дел, рассмотренных третейскими судами за длительный промежуток времени [7].

С принятием Устава Гражданского судопроизводства (20.11.1864), нормы, посвященные деятельности третейского суда, были включены во вторую главу, при этом, ст. 1400 Устава предусматривалось, что правила, изложенные в данном разделе, применяются и третейским судам, устанавливаемых по делам торговым, подведомственным судам коммерческим[8].

В частности, было определено, что стороны вправе поручить разрешение возникающих между ними споров одному или нескольким посредникам, избирае- мых в нечетном числе, по взаимному согласию сторон (ст. 1367), согласие сторон на рассмотрение дела третейским судом оформлялось письменно - третейской записью (ст. 1369), которая подписывалась сторонами и всеми посредниками, обязанными выразить согласие на принятие посредничества (ст. 1370).

Предусматривалось, что в третейской записи должны быть указаны данные сторон, посредников, сведения о предмете спора, также могли быть указаны сведения о месте заседания посредников, виде делопроизводства и порядке хранения документов, порядке объяснения сторон, сроках рассмотрения дела и иное (ст. 1371). Общий срок рассмотрения дела посредниками устанавливался продолжительностью в четыре месяца (ст. 1372), но он мог быть продлен либо изменен в третейской записи.

Допускалась замена посредников до окончания рассмотрения дела - по согласию сторон, по требованию одной из сторон (в случаях, предусмотренных законом) (ст. 1376).

Посредники не были связаны требованиями к соблюдению процедуры судопроизводства, но должны были соблюдать условия, содержащиеся в третейской записи (ст. 1378).

Решение по спору принималось посредниками большинством голосов и подписывалось ими (ст. 1388), в случае несогласия кого-либо из посредников с общим мнением, он был вправе отказаться от подписи, о чем делалась соответствующая отметка на решении (ст. 1391).

Решения третейского суда не подлежали обжалованию в апелляционном порядке (ст. 1393), но могли быть признаны недействительными по основаниям, предусмотренным в законе (ст.ст. 1396-1397).

Таким образом, следует заключить, что опыт разрешения споров в результате примирительных процедур, в том числе - с помощью специально привлеченных лиц, имелся в правоприменительной практике как Древней Руси, так и дореволюционной России.

Может ли что-либо из данного опыта быть использовано в медиации и судебном примирении сегодня? Очевидно, что на данном этапе развития российского законодательства и российской правовой науки подобное представляется возможным, но маловероятным. Действительно, в настоящее время сложно представить ситуацию, при которой за сторон будут договариваться выбранные кем-то лица, решение которых, по своей сути, будет являться для сторон обязательным. Также отсутствует и возможность разрешать спор, 
руководствуясь общими требованиями справедливости, поскольку, неизбежно, разрешение споров должно происходить с учетом принципа законности.

Между тем, очевидно, что институты медиации и судебного примирения нуждаются в дальнейшем развитии, в том числе - путем совершенствования правового регулирования. Возможно, что определенные черты вышеуказанных примирительных процедур с участием посредников, могли быть восприняты современным законодателем. В том числе - невозможность либо сокращенные сроки и основания для обжалования судебного постановления, принятого по результатам процедур медиации и судебного примирения, замена кандидатуры медиатора (судебного примирителя) в ходе данных процедур, и иное.

\section{ЛИТЕРАТУРА}

1. Гражданский процессуальный кодекс Российской Федерации// URL: http://www.consultant.ru/document/cons_doc_LAW_39570/ (дата 0бращения 14.06.2021)

2. Федеральный закон от 27.07.2010 № 193-Ф3 «06 альтернативной процедуре урегулирования споров с участием посредника (процедуре медиации)»// URL: http://www.consultant.ru/document/cons_doc_LAW_103038/(дата обращения 14.06.2021)

3. Давыденко Д.Л. Примирительные процедуры в российской правовой культуре: мировой ряд - особый способ урегулирования споров в Новгородской республике в XI-XV вв. // Третейский суд. 2011. № 3 (75).

4. Ключевский В.О. Русская история: полный курс лекций; в 3 кн. М., 1995. Кн. 3.

5. Мартышин О.В. Великий Новгород. Общественно-политический строй и право феодальной республики. М., 1992.

6. Великий Новгород. История и культура IXXVII веков. Энциклопедический словарь/под ред. О.А. Потанина, Н.Я. Яковлева. — СПб., 2008.

7. Материалы по судебной реформе в России 1864 года: [т. 1-74]. — Санкт-Петербург, 1857-1866. - (Проекты Второго отделения Собственной Его Императорского Величества канцелярии) (Работы Государственной канцелярии с 1857 по 1861 г.). Электронный ресурс]. — Режим доступа: URL: https:// www.prlib.ru/item/343167(дата обращения 14.06.2021).

8. Устав гражданского судопроизводства [Электронный ресурс]. - Режим доступа: URL: http://pravo.gov.ru/proxy/ips/?searchres=\&empire=1\&collectio $\mathrm{n}=0$ \&volume $=100020 \& \mathrm{pg}=244 \&$ contentsname $=\% \mathrm{C3} \% \mathrm{~EB} .+\mathrm{I} .+\% \mathrm{CE}+\% \mathrm{EC} \% \mathrm{E} \%$ F0\%EE\%E2\%FB\%F5+\%F1\%E4\%E5\%EB\%EA\%E0\%F5,+\%F1\%F2.+13571366.\&sort=1 (дата обращения 14.06.2021).

\footnotetext{
( Б) Баранов Геннадий Александрович ( GennadyyBaranov@yandex.ru ).

Журнал «Современная наука: актуальные проблемы теории и практики»
}

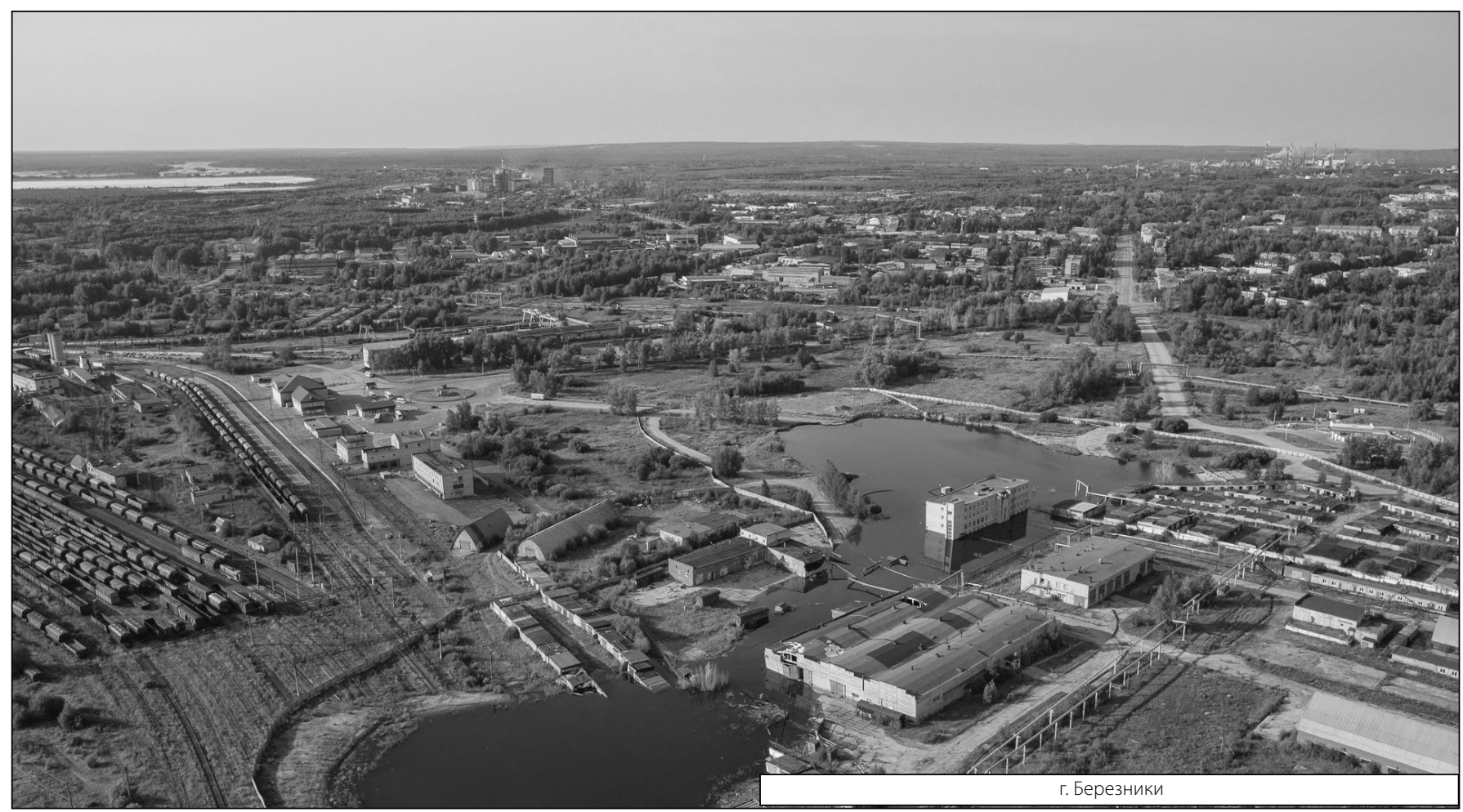

